\title{
Electronmicroscopic Study of Nanolike Bacteria
}

\author{
Karlen Hovnanyan', Margarita Hovnanyan', Armen Trchounian ${ }^{2 *}$ \\ ${ }^{1}$ Institute of Molecular Biology, National Academy of Sciences of Armenia, Yerevan, Armenia \\ ${ }^{2}$ Department of Biochemistry, Microbiology and Biotechnology, Yerevan State University, Yerevan, Armenia \\ Email: *Trchounian@ysu.am
}

How to cite this paper: Hovnanyan, K., Hovnanyan, M. and Trchounian, A. (2017) Electronmicroscopic Study of Nanolike Bacteria. Open Access Library Journal, 4: e3485.

https://doi.org/10.4236/oalib.1103485

Received: February 28, 2017

Accepted: May 2, 2017

Published: May 5, 2017

Copyright $\odot 2017$ by authors and Open Access Library Inc.

This work is licensed under the Creative Commons Attribution International License (CC BY 4.0).

http://creativecommons.org/licenses/by/4.0/

\begin{abstract}
Nanobacteria individual cases under the name of suggesting the bacteria mycoplasma and L-transformed forms of bacteria that imitate their size are nanobacteria that a separate systematic units remains controversial; the introduction of new high-resolution analytical microscopy techniques of prokaryote and eukaryote has revealed new structures in the structures of bacteria, which are the target of physical, chemical and biologically active stressors. The purpose of this work is, through a comparative retrospective analysis, to find out the motivation of "nanobacteria" ultrastructure public and visualize the structure of Gram-negative bacteria and viruses like symbiont of entamoeba.
\end{abstract}

\section{Subject Areas}

Cell Biology

\section{Keywords}

Nanolike, Bacteria, Symbiont, Electron Microscopy

\section{Introduction}

At the present time, despite the large number of publications about nanobacteria [1] [2] [3], the issues on their presence as a separate systematic units remain controversial. For the characterization of bacteria as "nanobacteria", they can be attributed to the filtering of L-transformed forms, to mycoplasmas and to dormant forms of the bacteria [4] [5]. Introduction to new high-resolution analytical microscopy techniques of prokaryotes and eukaryotes has revealed new structures in constructing of uncultivated bacteria and symbiont of entamoeba [6], which are the target of physical, chemical and biological active stressors factors. To nanobacteria, as to pathogenic factors, they are attributed such diseases as kidney stone disease, calcification of the placenta, malignant tumors and other diseases [7]-[9]. Study of nanobiotes and mixing them with nanobacteria, cal- 
cium and other mineral salts will probably make reveal etiological factors for various pathologies, as well as the mechanisms of formation of biofilm from bacteria [10]-[12].

The purpose of this work: through a comparative retrospective analysis to find out the ultrastructure motivations of publicly available visualized nanolike structures of bacteria and endosymbiont of entamoeba.

\section{Material and Methods}

\subsection{Experimental Materials}

In this study has been used a wide range of cultures of micro-organisms, belonging to different taxonomic groups causative agents of intestinal infections: enteropathogen Escherichia coli (strain 1257), Shigella flexnerii (strain 130), Salmonella typhimurium (strain 546), Entamoeba moshkovskii (strain "Er"). E. coli 1257 and S. flexnerii 130 and S. typhimurium 546, in order to follow the changes in bacterial cells in death phase of growth and after the treatment of antibiotics.

Bacteria were grown anaerobically in LB medium ( 48 hours, $37^{\circ} \mathrm{C}$ ), solidified with $1.8 \%$ agar, when necessary. The following antibiotics were used: ampicillin (35 $\mu \mathrm{g} / \mathrm{ml})$, and the quaternary ammonium compound (QAC) -“A -660" (0.5 $\mathrm{mg} / \mathrm{ml})$. The latter was done by serial dilutions as well as according to the instructions of bactericidal properties of new disinfectants. Ultrastructure analysis of antibiotics action was carried out according to the methods of determining the minimum inhibitory concentration (MIC) of antibiotics of the penicillin series-ampicillin (4000 units/ml) was used. The E. moshkovskii "Yer" cultures (wastewater treatment plant is off) were irradiated with lethal doses 1000 Grey of $\gamma$-ionizing radiation.

\subsection{Preparation of Specimens for Electron Microscopy}

Cell cultures of bacteria and entamoeba were separated after centrifugation at low speeds for/during $20 \mathrm{~min}$, and were fixed with $2.5 \%$ glutaraldehyde in $0.1 \mathrm{M}$ cacodylate buffer at $\mathrm{pH} 7.4$ during $2 \mathrm{~h}$. After washing three times in cacodylate buffer, the post-fixation was performed with the help of $1 \%$ osmium tetroxide in $0.1 \mathrm{M}$ cacodylate buffer at $\mathrm{pH} 7.4$ during at least $1 \mathrm{~h}$. After washing in the same buffer, dehydratation of biological samples was performed with ethanol or acetone of increasing concentrations (30\%, 50\%, 70\%, 96\% and 100\%), followed by impregnation and by pouring the mixture of araldite according to Luft [13]. After polymerization in the thermostat at temperatures of $37^{\circ} \mathrm{C}$ and $59^{\circ} \mathrm{C}$, we obtained ultrathin sections on the ultramicrotome "Reichert-Jung" (Austria). Ultrathin sections were then stained with aqueous uranyl acetate and 3\%, and by Reynolds lead citrate [14]. They were registered in the transmission electron mi-

croscope (TEM) JEM-100C and Tesla-500, operating at accelerating voltage of $80 \mathrm{kV}$. Electron microscopy imaging analysis was performed using the digital program system "Video-Test Structure-5 of Nanotechnology". 


\section{Results}

The formation of spherical granules in 40 - $100 \mathrm{~nm}$ surrounding by membrane structures of $S$. flexnerii in growth and death phase (Figure 1(a) Figure 1(b)), leaving the cell vacuoles unicultived forms of bacteria differing with compact citoplasme (Figure 1(c)), as well as the formation of outgrowths on S. typhimurium cell walls with different length during the ampicillin-treatment (Figure $1(d)$ ) were detected in these studies. These formations could be discussed as a basis for the development of nanobacteria under the specific conditions of environment [15].

After the action of the quaternary ammonium compound A-660 on E.coli, was detected the formation of "nanobacteria", which had the structure of Gramnegative bacteria, closely adjacent to the surface of the cell wall of $E$. coli (Figure 2 (a) Figure 2(b)). Some of them are connected by the little bridge to the cell wall of bacteria, thus creating the appearance of budding. In the same biosamples, were installed the outgrowths of the cell wall of the outer membrane of various lengths (Figure 2(c)).



(a)



(b)

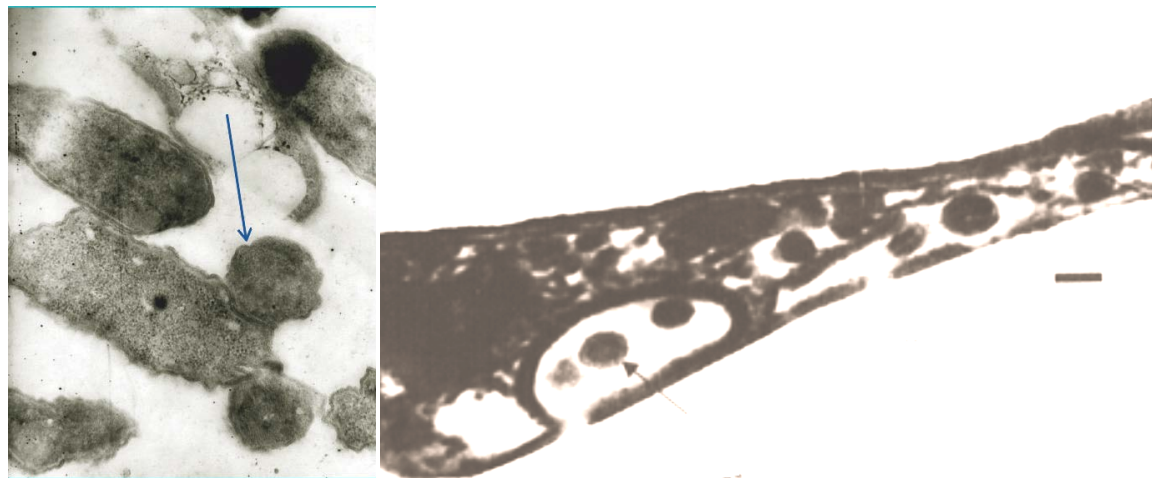

(c)

(d)

Figure 1. (a)-(d) TEM. Ultrathin section Shigella flexnerii (strain "120") (a). Stationary phase growth of the culture, leaving "nanobacteria" spherical bodies $(\rightarrow)$. Magn. $\times 50,000$; (b) TEM. Ultrathin sections Shigella flexnerii. Out nano-like bacteria from the vacuole (1b) Magn. $\times 30,000$; (c) TEM. Ultrathin section. Leaving the cell vacuoles Shigella flexnerii uncultivated forms of bacteria differing with compact cytoplasm; Magn. $\times 30,000$; (d) TEM. Ultrathin section Salmonella typhimurium (strain 546) after subdrug action ampicillin. Formation granules of nano-like bacteria. Mag. $\times 30,000$. 
At nano-like symbiotic bacteria of Ent. moshkovskii, after exposure to $\gamma$ - radiation, have been identified previously unknown structures in the form of electron dense granules with different diameter from 8 to $35 \mathrm{~nm}$ (Figure 3). The particles " $\mathrm{O}_{1}$ " on ultrathin sections were examined it should be said that the diameter of the large granule " $\mathrm{O}_{1}$ " was $35 \mathrm{~nm}$, the area- $885 \mathrm{~nm}^{2}$; and the diameter of the small " $\mathrm{O}_{2}$ "- $8 \mathrm{~nm}$, the area- $45 \mathrm{~nm}^{2}$. After irradiation, the morphometric parameters of virus-like symbionts, on ultrathin sections, were equated in length within $160 \mathrm{~nm}$ in diameter- $94 \mathrm{~nm}$, the total area-11036 nm². "O $\mathrm{O}_{1}$ " granules with their electron density and sizes resemble volutin-acidocalcisom (AC) (Figure 3) of bacteria and unicellular eukaryotes after the action of stress factor [16].

One can consider the formation of nano-like bacteria as one of the forms of survival of bacteria and symbionts under the influence of stress factors. The results of our searches have shown various forms of nanosphere transformation under the action of antibiotics, quaternary ammonium compounds and ionizing radiation, which is comparable with the literature data of nanomicrobiology [2] [12].

\section{Conclusions}

The data we obtained witness the fact that the formation of nano-like structures

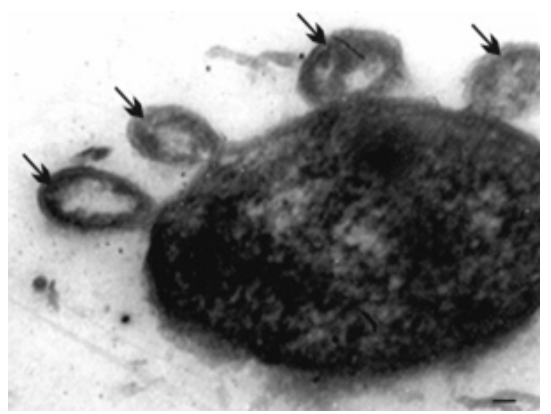

(a)

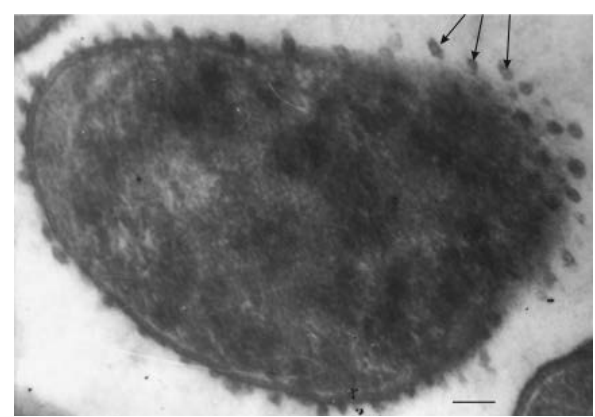

(b)

Figure 2. (a) TEM. Ultrathinsections of E. coli (strain 1257) The action of the quaternary ammonium compound to $E$. coli. Formation of nano-like bacteria on the surface of bacteria cells. ( $\rightarrow$ on E. coli); Magn. $\times 3000$; (b) TEM. Ultrathin sections of $E$. coli (strain 1257). The action of the quaternary ammonium compound to $E$. coli. Protuberances $(\rightarrow)$ of the outer membrane of the cell wall of bacteria. ( $\rightarrow$ on $E$. coli). Magn. $\times 30,000$.

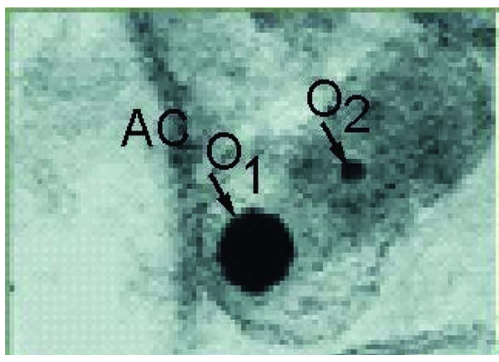

Figure 3. TEM. Ultrathin section of symbiont of Entamoeba moshkovskii (strain Yer.). It is seen the volutin-acidocalcisom-like (AC) electron dense granule under cover symbiont $\left(\rightarrow \mathrm{O}_{1}\right)$ and nanoparticle $\left(\rightarrow \mathrm{O}_{2}\right)$. Electron microscopy imaging analysis was system "Video-Test Structure-5 of nanotechnology." Magn. $\times 100,000$. 
in/at E. coli, Shigella flexnerii, Salmonella typhimurium was type connected with the cultures aging, as well as by the action of bio-organic, chemical and physical stress factors of the environment, as well as they testify the possibility of the presence of acidocalcisome in nanobacteria of symbionts in entamoeba cells with $\gamma$-ionizing radiation.

Our attempts to analyze nanobacteria-like formations and the obtained results allowed to establish different types of nanostructures in studied Gram-negative bacteria and symbiont of entamoeba performed using the digital program.

\section{Acknowledgements}

The study was done within the framework supported by Ministry of Education and Scene of the Republic of Armenia (Basic support).

\section{Conflict of Interests}

The authors declare no conflict of interests with respect to the present paper.

\section{References}

[1] Kajander, E.O. (2006) Nanobacteria-Propagating Calcifying Nanoparticles. Letters in Applied Microbiology, 42, 549-552. https://doi.org/10.1111/j.1472-765x.2006.01945.x

[2] Robert, J.C., Mc Lean, B. and Kirl, L. (2014) Nanostructure and Nanobacteria. In: Barton, L.L., Bazilski, D. and Xu, H., Eds., Nanomicrobiology: Physological and Environmental Characteristics, Springer-Verlag, $125 \mathrm{p}$.

[3] Wu, C.-Y., Young, D., Martel, J. and Young, J.D. (2015) A Story Told by a Single Nanoparticle in the Body Fluid: Demonstration of Dissolution-Reprecipitation of Nanocrystals in a Biological System. Nanomedicine, 17, 2659-2676.

https://doi.org/10.2217/nnm.15.88

[4] Timakov, V.D. and Kagan, G.Ya. (1973) L-Form of Bacteria and Family Mycoplasmataceae in Pathology. Medicine, Moscow, 385 p.

[5] Shimizu, T. and Miyata, M. (2002) Microscopic Studies of Three, Gliding Mycoplasmas Mycoplasma Mobile, M. pneumoniae, and M. gallisepticum, by Using the Freeze-Substitution Technique. Current Microbiology, 44, 431-434. https://doi.org/10.1007/s00284-001-0014-8

[6] Hovnanyan, K.O., Davtyan, H.H., Sargsyan, Ch.A. and Trchounian, A.A. (2010) Nanostructures of Some Viruses, Bacterial and Protozoa Cells: Electron Microscopy and Morphometrical Analysis. NAS RA Reports, 110, 277-284.

[7] Liu, S.N., Zhang, D.C., Zhang, M.J., Guo, Y.N., Yang, X.R. and Yang, S.J. (2013) Morphological Observation of Nanobacteria in Calcified Placenta and Umbilical Cord Blood. Chinese Journal of Clinical Laboratory Science, 3, 215-217.

[8] Zhang, M.J., Liu, S.N., Xu, G., Guo, Y.N., Fu, J.N. and Zhang, D.C. (2014) Cytotoxicity and Apoptosis Induced by Nanobacteria in Human Breast Cancer Cells. International Journal of Nanomedicine, 9, 1-7.

[9] Khullar, M., Sharma, S.K., Singh, S.K., Bajwa, P., Shiekh, F.A., Relan, V. and Sharma, M. (2004) Morphological and Immunological Characteristics of Nanobacteria from Human Renal Stones of a North Indian Population. Urological Research, 32, 190-195. https://doi.org/10.1007/s00240-004-0400-3

[10] Hovnanyan, K., Marutyan, S., Pepoyan, A., Navasardyan, L. and Trchounian, A. 
(2015) Transmission and Scanning Electron Microscopy of Contacts between Bacterial and Yeast Cells in Biofilms on Different Surfaces. Open Access Library Journal, 2, 1-8. https://doi.org/10.4236/oalib.1101492

[11] Schwartz, M.K., Hunter, L.W., Huebner, M., Lieske, J.C. and Miller, V.M. (2009) Characterization of Biofilm Formed by Human-Derived Nanoparticles. International Journal of Nanomedicine, 4, 931-941. https://doi.org/10.2217/nnm.09.72

[12] Martel, J., Peng, H.-H., Young, D., Wu, C.-Y. and Young J.D. (2014) The Nanobacteria, Nanoparticles, Biofilms and Their Role in Health and Disease: Facts, Fancy and Future. International Journal of Nanomedicine, 9, 483-499.

https://doi.org/10.2217/nnm.13.221

[13] Luft, J.H. (1961) Improvements in Epoxy Resin Embedding Methods. Journal of Biophysical and Biochemical Cytology, 9, 409-414.

https://doi.org/10.1083/jcb.9.2.409

[14] Venable, J.H. and Coggeshall, R. (1965) A Simplified Lead Citrate Stain for Use in Electronmicroscopy. Journal of Cell Biology, 25, 407-408.

https://doi.org/10.1083/jcb.25.2.407

[15] Hovnanyan, M., Pepoyan, A. and Hovnanyan, K. (2016) Formation of Bacterial Nanostructures: The Impact of Growth Dead Phase and Antibiotics. European Microscopy Congress, 115-116. https://doi.org/10.1002/9783527808465.emc2016.6400

[16] Seufferheld, M., Mauricio, C.F., Ruiz, V.F.A., Rodrigues, C.O., Moreno, S.N.J. and Docampo, R. (2003) Identification of Organelles in Bacteria Similar to Acidocalcisomes of Unicellular Eukaryotes. Journal of Biological Chemistry, 278, 2997129978. https://doi.org/10.1074/jbc.M304548200

Submit or recommend next manuscript to OALib Journal and we will provide best service for you:

- Publication frequency: Monthly

- 9 subject areas of science, technology and medicine

- Fair and rigorous peer-review system

- Fast publication process

- Article promotion in various social networking sites (LinkedIn, Facebook, Twitter, etc.)

- Maximum dissemination of your research work

Submit Your Paper Online: Click Here to Submit

Or Contact service@oalib.com 